\title{
The Problems and Suggestions on Education of Transition from Kindergarten to Primary School in Zhoushan City
}

\author{
Nvjie Guo \\ Zhejiang Ocean University, Zhoushan, China \\ Jingjing $\mathrm{Lu}$ \\ Zhejiang Ocean University, Zhoushan, China \\ Zhijie Chen \\ Zhejiang Ocean University, Zhoushan, China \\ Han Xiao \\ Zhejiang Ocean University, Zhoushan, China
}

\begin{abstract}
Education transition from kindergarten to primary school is an educational process, and it is also an important turning point in child development. Physical and mental developments of children are different in kindergarten and primary school. It is important to make a smooth transition from kindergarten to primary school, in order to promote sustainable development and improve education quality. The Learning and Developing Guidelines for 3-6 Child stipulates Kindergarten should work in close cooperation with family and community, connect with primary school, make good use of all education resources, and create favorable conditions for child development together .Our research group took six months to survey the implementation of education of transition from kindergarten to primary school in Zhoushan. Using the methods of field trips, interview and questionnaire, our group gathered the real, effective information and data to identify the problems about transition, and give some reasonable suggestions.
\end{abstract}

Index Terms - transition from kindergarten to primary school, preschool education, Zhoushan

\section{INTRODUCTION}

In September of 2015, Zhejiang Provincial Education Office issued the guideline about the education of transition from kindergarten to primary school, which indicated that kindergarten can't teach children the content of primary school curriculum. However, the guideline is not consistent with children' cognitive ability required by primary school. So cram schools are playing an important role in this process, but they are uneven in educational qualification, reputation, teaching level, teaching environment, safety, and charging standard, which become a focus in Zhoushan and generate a great influence on the quality of primary education.

What's more, because of the special geographical location, unique population structure and rapid development speed of Zhoushan, it is urgent to find out suitable solutions based on the reality. With the establishment of Zhoushan Archipelago New District, we need to solve these problems to improve the development speed. On the basis of these related researches, this project will focus on the practical problems of education of transition from kindergarten to primary school in Zhoushan, and propose corresponding suggestions and solutions to improve the education quality of Zhoushan.

\section{LITERATURE REVIEW}

\section{A. Overview of Foreign Studies}

On the whole, foreign countries begin studying the education transition from kindergarten to primary school earlier, and some achievements have been made in relevant fields.

1. About the Content of Education Transition

The National Education Goal Panel (NEGP) of US argues that school readiness of children should embody five fields consisting of physic health and sports, learning style, social development, language development and cognitive and common knowledge fields ${ }^{1}$. the five fields has got the international acknowledgement, but different countries have

\footnotetext{
1 The National Education Goal Panel: Reconsider children's early development and learning: move towards common idea and vocabulary [R]Washington D.C National education target group, 1995
} 
different descriptions according to national conditions.

2. Parents' Concept about Education Transition

As the first teacher of kids, parents have big influences on children' adaption that are reflected on behavior habits, character formation, interpersonal interaction and so on. According to the survey of these parents whose children lay in the stage of transition from kindergarten to primary school, McIntyre comes to the conclusion that the parents who are willing to invest energy and money on children, compared with those parents do not understand and have no intention to understand the knowledge of the transition, tend to finish the work of transition more successfully, but study shows that parents are completely unaware of the expectations of the school. Meanwhile, he concludes that if parents' opinions are in line with the school's view, children can make full preparation with the help of parents, and vice versa.( McIntyre, 2007).

\section{B. Domestic Research Review}

In recent years, China attaches greater importance to the education transition from kindergarten to primary school. The research results are becoming increasingly prominent.

\section{About the Content of Education Transition}

Qiyun Sun and Dingwei Hu (2000) point out that children's logical thinking, language expression, observation ability, and creativity should be cultivated during the transition from kindergarten to primary school. Xiuru Zhang (1995) advocates that primary school should cultivate children's study habit and life habit, meanwhile, in order to lessen the burden, school can teach in the form of sub-division teaching, so that children can have a positive attitude to school. Xiaoping Yang (2004) illustrates that the cohesion of Chinese curriculum should start from course objectives, course content, course organization, curriculum implementation, and course evaluation.

2. Parents' Concept about Education Transition

According to the study about the educational concept of parents and kindergarten teachers, Lingling Li (2013) argues that they have realized this transition is a good guarantee for children' study, both parents and teachers agree that. But it is generally acknowledged that Chinese parents emphasize more on intellectual education and underestimate moral education, aesthetic education and sports. Meanwhile, Chinese parents who have different occupations, education backgrounds, and incomes have different educational concepts. The concepts of parents are closely related to the state of children during the transition from kindergarten to primary school. Houyu Wang (2012) concludes some major problems after study, such as excessive emphasis on grades, ignorance of children's comprehensive development; unscientific educational concepts, which result in that children cannot adapt to the change of learning environment.

\section{RESEARCh METHODS AND DATA}

\section{A. Sample}

Our group carries out questionnaire investigation in 10 kindergartens and primary schools in Zhoushan city in Zhejiang province. We randomly select about 360 parents and teachers in different grades of kindergarten. A total of 360 questionnaires were collected by using online questionnaire. As for the parents and children primary school, we mainly use the method of interview.

Among the respondents, $54.44 \%$ children are male, and $45.56 \%$ children are female. $17.22 \%$ children are from junior class of kindergarten, $46.67 \%$ children are from mid-class of kindergarten and $36.11 \%$ children are from senior class of kindergarten.

\section{B. Research Method}

By using the methods of questionnaire (the content of the questionnaire covers the condition of children, including the gender, family structure, education and the parents, including the attitude, worries and suggestion to transition from kindergarten to primary school), on-the-spot investigation and interview, we collected the information and data in order to find out the differences and vulnerabilities.

\section{Research Results and Date Analysis}

TABLE 1

PARENTS AND TEACHERS' ATTITUDES TO THE EDUCATION TRANSITION FROM KINDERGARTEN TO PRIMARY SCHOOL

\begin{tabular}{|l|l|l|}
\hline Degree & Number & Rate \\
\hline very important & 264 & $73.91 \%$ \\
\hline important & 84 & $22.36 \%$ \\
\hline less important & 12 & $3.73 \%$ \\
\hline unimportant & 0 & $0 \%$ \\
\hline
\end{tabular}

From table 1, it's easy to notice that $96.27 \%$ parents attach much attention to the transition. $3.73 \%$ parents pay less attention to it, and no parents think it unimportant. 
TABLE 2

PARENTS AND TEACHERS' OPINION TO THE CONTENT OF THE TRANSITION FROM KINDERGARTEN TO PRIMARY SCHOOL

\begin{tabular}{|l|l|l|}
\hline Content & Number & Rate \\
\hline knowledge reserve & 191 & $53.11 \%$ \\
\hline reading Chinese characters & 128 & $35.56 \%$ \\
\hline writing Chinese characters & 94 & $26.11 \%$ \\
\hline arithmetic & 99 & $27.5 \%$ \\
\hline Pinyin $^{2}$ & 132 & $36.67 \%$ \\
\hline learning ability & 237 & $65.83 \%$ \\
\hline learning interest & 323 & $89.72 \%$ \\
\hline living ability & 291 & $80.83 \%$ \\
\hline habit formation & 331 & $91.94 \%$ \\
\hline social ability & 255 & $70.83 \%$ \\
\hline The willingness for school & 181 & $50.28 \%$ \\
\hline others & 12 & $3.33 \%$ \\
\hline
\end{tabular}

From table 2, as for the content of the transition from kindergarten to primary school, habit formation, learning interest and living ability rank the top 3 .According to degree of the importance, the last three are reading Chinese characters, writing Chinese characters and arithmetic. For teachers and parents, the concept of preparation has been converted from merely learning specific knowledge to comprehensive preparation. Most teachers and parents consider that school readiness should be comprehensive, which consists of living habit, learning habit, learning ability, self-care ability, rule consciousness, test consciousness and physical quality, instead of only studying Chinese characters and Pinyin.

TABLE 3

THE WILL FOR LEARNING PRIMARY SCHOOL CURRICULUM OF PARENTS

\begin{tabular}{|l|l|l|}
\hline Will & Number & Rate \\
\hline Yes & 243 & $67.5 \%$ \\
\hline No & 117 & $32.5 \%$ \\
\hline
\end{tabular}

TABLE 4

THE WAY TO LEARN PRIMARY SCHOOL CURRICULUM

\begin{tabular}{|l|l|l|}
\hline Way & Number & Rate \\
\hline Studying at home & 116 & $47.93 \%$ \\
\hline Studying at cram school & 126 & $52.07 \%$ \\
\hline
\end{tabular}

From table 3 and table 4, it's easy to notice that $67.5 \%$ parents are willing to let their children get access to primary school curriculum. As for the way of learning, $47.93 \%$ parents choose to teach the children by themselves, and $52.07 \%$ parents choose to learn at cram school.

TABLE 5

ACTIVITIES ORGANIZED BY THE KINDERGARTENS

\begin{tabular}{|l|l|l|}
\hline Activities & Number & Rate \\
\hline $\begin{array}{l}\text { visiting primary school campus to get } \\
\text { familiar with the school life }\end{array}$ & 194 & $53.89 \%$ \\
\hline $\begin{array}{l}\text { Help students cultivate good study and } \\
\text { life habits }\end{array}$ & 280 & $77.78 \%$ \\
\hline Cultivate social adaptability & 181 & $50.28 \%$ \\
\hline $\begin{array}{l}\text { add some primary school learning } \\
\text { content }\end{array}$ & 71 & $19.72 \%$ \\
\hline $\begin{array}{l}\text { invite primary school teachers to guide } \\
\text { the transition }\end{array}$ & 136 & $37.78 \%$ \\
\hline $\begin{array}{l}\text { invite parents to discuss how to organize } \\
\text { activities for the transition }\end{array}$ & 138 & $38.33 \%$ \\
\hline others & 23 & $6.39 \%$ \\
\hline
\end{tabular}

Table 5 shows that kindergartens pay more attention to cultivate better learning and life habits and social adaptability for children during the process. Most kindergartens lead children to visit primary school campus, and then join in the class, in order to experience different life and environment. However, many interviewees express that the kindergartens only organize this kind of activity once or twice in the second semester of senior grade, which only lasts half a day. Therefore, these activities have no substantive effect at all.

\footnotetext{
${ }^{2}$ A kind of pronunciation rule
} 
TABLE 6

DIFFICULTIES THAT CHILDREN MAY CONFRONT IN FIRST GRADE IN PRIMARY SCHOOL

\begin{tabular}{|l|l|l|}
\hline Difficulties & Number & Rate \\
\hline longer class time & 219 & $60.83 \%$ \\
\hline change of the schedule & 102 & $28.33 \%$ \\
\hline change of teaching style & 136 & $37.78 \%$ \\
\hline making new friends & 88 & $24.44 \%$ \\
\hline lack of interest to subject & 164 & $45.56 \%$ \\
\hline peer pressure & 63 & $17.5 \%$ \\
\hline incomprehension of the course & 120 & $33.33 \%$ \\
\hline unable to keep up with the teacher in class & 207 & $57.5 \%$ \\
\hline unable to put away learning tools & 130 & $36.11 \%$ \\
\hline unable to take notes & 188 & $52.22 \%$ \\
\hline others & 22 & $6.11 \%$ \\
\hline
\end{tabular}

Table 5 shows that the biggest worry for the parents whose children is going to enroll is that children cannot behave themselves well and then have difficulty in keeping up the pace of teacher. Therefore, most parents let the children study pinyin, Chinese characters and simple math before enrollment. And that's the reason why many cram schools enjoy the popularity among the parents.

\section{DisCuSSION ABOUT THE PROBLEMS}

\section{A. Superficial and Unilateral Practice of Parents and Teachers}

In the interview, when asked about the suggestions to the transition, most parents voice that the kindergarten should add the primary school curriculum to the teaching content to a certain degree, such as Pinyin, sums and literacy. And in this way they can avoid spending extra money on cram school. However, the tendency to teaching primary school curriculum in kindergarten becomes more and more popular in a few kindergartens (especially private and township kindergartens), and they will design the course related to the primary school curriculum to satisfy these parents and attract students.

Our research found most parents have realized the importance of the transition, and pay attention to children's comprehensive education. The transition is not only preparation of knowledge but also the preparation in life habit, study habit and study ability. But in practice, parents engagement is not enough and put too much emphasis on children' grades.

\section{B. Lacking of Scientific and Effective Joint between Primary School and Kindergarten}

Kindergarten and primary school are totally different, one focus on games, and the other centers on learning knowledge. During the transition from the kindergarten to primary school, the key to success is to realize the child's own role conversion. If we can't achieve that, children will run into a great deal difficulties after entering primary school. Therefore, the primary focus should be on the seamless connection between kindergarten and primary school. But the two sides have not set up an intact and valid system to handle the problem. And Cram schools spring up in response to this condition, which makes the problems more complicated to handle.

Besides, the Education Bureau in Zhoushan states that kindergartens can't teach kids courses which belong to primary school teaching content. It means kindergarten teachers shouldn't teach kids arithmetic, pinyin and Chinese characters. However, when kindergartens invite primary school teachers to guide the work, some of them assert some definite requirements to children: first of all, children must master Pinyin and add and subtract within 20. Besides, some primary schools request children to know less than 300 Chinese characters. We interview a number of teachers to obtain the teaching process of pinyin, they express that the teaching cycle lasts for only one month. Because they have known that most children had learned before enrolling. Therefore, the stipulation of Education Bureau runs counter to the reality. That's the reason why parents worry and fear.

\section{Lacking of Valid Communication and Cooperation between School and Family}

Parent is the first and lifetime teacher of children, so the transition needs parents' participation. Our research finds that school and family lack of valid communication and cooperation in course of the interview. School invite parents to join in some activities such as parent forum, parent meeting, and so on, but low frequency, poor efficiency, and formulaic burdens also exist now.

Besides, due to traditional concept and diversified nurturing attitudes, many parents pay more attention to advanced training rather than lifelong development, so children are requested to master the textbook knowledge that will be taught in the first grade of primary school. The result is children have trouble in adapting new surroundings. At the beginning, they are inattentive in class and careless in homework because they think it is so easy. Then they develop bad learning attitudes and habits. Finally, with the increasing difficulty in study, children will be left behind for lacking a good learning habit. In fact, these parents generate more pressure on kindergarten and primary school in pedagogical practice, some even become obstruction during the transition. 


\section{SugGestions}

\section{A. Respect Children's Right of Speech, Design and Implement Preschool Education Programs from Child's Perspective}

Children's right of speech has been recognized as an increasingly important part that deserve to be protected. Convention on the Rights of the Child (commonly abbreviated as the CRC or UNCRC) allows us to take a fresh look at children as individuals, family members and members of the society who have rights and obligations appropriate to their age and stage. School-age children have already obtained a certain level of awareness and emotional attitude, they have their own views on the preschool education, and are able to put forward their own solutions to the problem in the process. However, schools and families tend to overlook children's right of speech without realizing children's ability to solve problems by themselves.

In preschool education, as adults, we should listen more to the voices of children and provide them with some discourse space, so that children can experience a sense of respect, a sense of ability as well as a sense responsibility and rights.

\section{B. Kindergarten and Primary School Should Work together to Achieve a Seamless Connection and Pave the Way for Children to Graduate from Kindergarten}

Education transition from kindergarten to primary school is a bi-directional joint connection between kindergarten and primary school, which demand the both sides to establish an equal and cooperative relation with each other to promote a smooth transition. In the past, the burden of this transition was mostly laid on the kindergartens side who make adjustments to their timetable, and occasionally organize a visit to primary schools. In addition, primary school teachers should also make effort to communicate with kindergarten teachers to study their educational theories, explore teaching methods, study children's psychological conditions, and actively explore ways and means suitable for young children. In order to smooth the transition, teachers should make efforts to strengthen the ties between the two parties. They should use diversified teaching and learning forms to gradually realize the curriculum convergence through small steps so that young children can adapt themselves to the transition more easily.

Concerned about the conditions of our country and this city, we can strengthen the connection between teachers of kindergarten and primary school from the following two aspects: the first one is to convene "question-and-answer meetings" to provide a platform in which teachers from both sides are able to talk and discuss, and on this basis, amend and perfect the kindergarten class plan; the second one is to organize informal discussion, experience introduction and mutual lectures to provide chances for the kindergarten teachers and primary school teachers to be familiar with the education methodology and characteristics of the other side and learn from each other.

\section{Strengthen Parents' Centrality in Preschool Education and Strengthen the Bonds between Families and School}

As children's first teacher, parents are the key members of preschool education. During the transition to primary school, it is a crucial period for the establishment of positive parent-child relationships in the family. Parents not only know their children's early experiences, but also have a more comprehensive understanding of their children's sociality, emotion regulation, learning foundation and self-management. What's more, parents are full of expectations for schooling and teachers, they are willing to engage in preschool education and offer practical help to teachers.

In the future training of kindergarten teachers, efforts should be made to highlight the core point of "home-school co-education.", which means that parents and teachers should have mutual contact and should be encouraged to communicate with each other. Parents should also be invited to participate in preschool education activities so that parents and teachers are able to guide each other and work together to help children adapt to the new environment as soon as possible.

\section{Learn from Advanced Foreign Experience to Improve the Quality of Preschool Education}

1. Formulate a scientific assessment system and employment standards and combine the training of teachers.

The United States develops a system of joint training of teachers of kindergarten and primary school, that is, a combination of kindergarten teachers training and primary school teachers training. Teachers' qualifications obtained after graduating from university cover the lower grades of primary schools and kindergartens. What's more, Japan also organized such kind of joint training and kindergarten teachers of Japan could participate in the examinations prepared for primary school teachers. At present, the training of kindergarten teachers and secondary primary schools in our city is separated. Lacking of understanding hinders the progress of convergence and urges us to take lessons from overseas training methods, and combine the training of kindergarten teachers with those of lower grades in primary schools. In the process of joint training, kindergarten teachers and lower primary school teachers can enhance their understanding and reach agreement on curriculum.

2. Enrich the curriculum organizations and pay attention to the continuity of the curriculum.

The theory of "Teaching Stage" formulated by French experts divides the preschool children and elementary school students into three stages: the stage of enlightenment education, the stage of basic study and the stage of in-depth education, in which the training objectives, curriculum plans or assessment criteria are interrelated and indivisible. Japan implemented a program of establishing schools that provide successive education during the kindergarten and 
primary school period. In its guideline on education in 2002 promulgated by the Ministry of Education promulgated "life lessons" for first- and second-year elementary school students, the most prominent feature of this course is its comprehensive inquiry, letting children explore all aspects of life in a variety of ways. The kindergarten curriculum in Britain and Sweden also attach great importance to the individual differences of young children by teaching students according to their different aptitude and characteristics, they pay much attention to the transition and integration of courses. Our city should also start to pay attention to the transition of kindergarten and primary school curriculum. For example, when organizing activities, we can expand related topics of kindergarten curriculum, set some theme activities such as "I want to go to primary school" and "Primary school in my eyes" so that children can perceive rules of primary school through activities and avoid the emergence of a knowledge fault. On the elementary school side, we should also adjust course content and activity form, adding interesting and inquiry-based activities to help children to cultivate their self-learning ability.

3. Create an environment suitable for the development of children to ensure environmental convergence.

Some states in the United States have kindergartens attached to primary schools so that young children can get acquainted with primary school environment, primary school life which is helpful for them to solve various adaptation problems caused by environmental changes. In addition, their activity room is basically the same as that of the lower primary school. The tables and chairs are arranged in a horseshoe shape. A small group of children sit around a table for operational activities or games. The instructor guides the collective activities quite flexibly and children can move freely according to the needs of the teaching content, sometimes teacher-centered, sometimes whiteboard-centered. Primary schools in our city should also show continuity in setting up their environment. For example, we can create science corners and art corner in the lower grades of primary school classrooms. Of course, the materials put on the corner of the activity area in primary school classrooms should be slightly different from those in kindergartens, showing progressiveness to meet the needs of children's development.

\section{E. Bring Government Management and Supervision into Full Play}

Preschool education is inseparable from the supervision, guidance and scientific management of the government and other education departments. We should learn from the experience of France and Japan, hiring educational consultants who have professional knowledge in both primary school and kindergarten. About the educational system, we should pay more attention to the organizational problems such as the number of teaching days, the number of class hours, and the student-staff ratio.

In addition, the government and education authorities can exert their influence through formulating policies by establishing clear, detailed and comprehensive laws and regulations to strengthen legislative guarantee so as to promote the implementation of preschool education. Government departments should also strongly encourage and support preschool education institutions to develop into a new stage that are not totally similar to "elementary schools", so as to create a new atmosphere in the early childhood education. Educational departments at all levels should strive to promote the balanced development of compulsory education and ban all types of enrollment examination and interview at primary school.

\section{CONCLUSION}

In this paper, the author discussed the status quo of the education transition from kindergarten to primary school and made corresponding suggestions. The problems have been received worldwide attention and a large number of researches conducted by developed countries have provided a lot of excellent experience for this topic.

American kindergartens are basically attached to primary schools, with children from 4 to 6 years old, as the "primary school ladder". For children aged 5 years before the first grade of primary school, the preparation of education for one year is mainly to promote the development of all aspects of children and prepare for entering primary school. On education content, it is emphasized that education content should meet the requirements of the times, and it will carry out education for children in mathematics and natural science.

Switzerland and Britain respect for the needs of the parents, and two grades in kindergarten are set in the same environment as the first and second grade of primary school. And Japan implements the transition from the perspective of lifelong education, and sets its goal to develop life skills and learn basic things.

Transition from kindergarten to primary school makes a good preparation for children both in mental and physical aspects, whose essence is to help children transform to formal primary education successfully and fit new environment, thus they have a balance between body and mind and then become a generation of all-round development in future. To achieve the goal, kindergarten, primary school and family should make concerted efforts.

All in all, the transition from kindergarten to primary school is a huge project, which is related to children' sustainable development. We should consider it under the background of lifelong education, instead of regarding it as a problem between the two education stages. Each party should plan as a whole, put children in the first place and strive for the smooth transition in Zhoushan city. 


\section{APPENDIX. QUESTIONNAIRE}

\section{幼小衔接教育情况调查问卷}

尊敬的家长:

您好！“孩子就要上小学了, 需要做些什么样的准备工作? ”这是每一位即将入学儿童的家长所关心的话题。 现就舟山幼小衔接教育情况进行如下调查, 以方便您对孩子入小学是否做好准备有所了解, 也便于我们的课题 研究学习。希望您在百忙之中能抽出半小时左右的时间如实填写此问卷, 以便于我们能收到最为真实详细的第 一手教育资料。

请您根据自己的实际情况认真完成全部题目。在确定的选项上打“V”或按要求填写。

十分感谢您真诚的合作！

一、基本资料

1、孩子性别：（1）男

(2) 女 年龄: 岁

2、孩子就读的学校（幼儿园）:

3、孩子所在的年级：（1）小班 （2）中班（3）大班
4、您的家庭结构:
(1) 三口之家
(2) 三代同堂

5、平时孩子的生活起居由谁照料?

(1) 父母

(2) 祖辈

6、学前阶段谁主要负责孩子的教育问题?

(1) 父母

(2) 祖辈

二、幼小衔接教育情况调查

1、您觉得“幼小衔接”工作对于幼儿入学的重要程度是
1) 非常重要
2) 重要
3) 一般
4) 不重要

2、您觉得幼小衔接工作都包括什么?（可多选）
1) 知识储备
2) 多认字
3) 写字
4）做算术 5）拼音
6）学习能力
7）学习兴趣
8）生活能

力 9）习惯养成 10）社会交往能力 11）上学的愿望

3、您觉得您的孩子对拼音 (认读写) 、汉字 (认读写) 、数学 (1-100 的认知; 20 以内的加减法) 的掌 握程度是
1) 很好
2) 一般
3) 比较吃力

4. 您的孩子对上小学的态度是怎样的?
1) 向往
2) 无所谓
3）恐惧

5、您会因为自己的孩子马上要上小学了, 便想让他们学一些接近小学的课程吗?

1) 是 2) 不是

如果是，采用何种方式？1）自己教

2) 培训机构学习

6、您的孩子即将上一年级, 最令您担心的事情是什么? (可多选)
(1) 上课时间长, 怕子孩子坐不住。
(2) 早上上学早, 起不来。
(3) 不习惯老师的教学风格。
（4）孩子不知道如何结交新朋友。
(5) 孩子不喜欢做功课。
(6) 孩子和同学比较成绩。
(7) 听不懂老师的话。
（8）动作慢, 跟不上学习节奏。
（9）不会整理、保管自己的学具。
(10) 不会听课做笔记。

11）其他: 如

7、您孩子所在的幼儿园开展了哪些幼小衔接活动？（可多选）

1) 带孩子参观小学校园, 走进一年级学生课堂, 熟悉小学学习和生活环境

2) 培养入学儿童良好的学习能力和生活习惯

3）培养入学儿童的社会适应性

4) 改进教学课程内容, 适当增加小学课程

5) 邀请小学老师或校长进园指导幼小衔接教育工作

6）邀请您共同探讨孩子如何步入小学的安排或参加一些相关的幼小衔接活动

7) 其他

8、您希望幼儿园对课程有所改进吗?
1) 希望
2) 不希望

如果希望, 有哪些

9、您会为孩子的幼小衔接做哪些准备? 希望幼儿园或小学为您孩子的幼小衔接做哪些准备工作?

\section{REFERENCES}

[1] Hong, X.M. \& Li, L \& Cui, F.F. (2013). Investigating Regional Disparities of Preschool Education Development with Cluster 
Analysis in Mainland China . International Journal of Child Care and Education Policy 7:67-80.

[2] Kang, J. \& Horn, M. E. \& Palmer, S. (2017). Influences of Family Involvement in Kindergarten Transition Activity on Children's Early School Adjustment, Early Childhood Education Journal 45: 789-800.

[3] Li, L.L. (2013). Study on the Parents' and Teachers' Conception of Matriculation and Readiness of Children. Hangzhou: Hangzhou normal university, 34-72.

[4] McIntyre, L. L. \& Eckert, T. L. \& Fiese, B. H. et al. (2007). Transition to Kindergarten: Family Experiences and Involvement. Early Childhood Education, 35(1): 83-88.

[5] Pinto, G \& Bigozzi, L. \& Vezzani C. et al. (2017) .Emergent Literacy and Reading Acquisition: a Longitudinal Study from Kindergarten to Primary School , European Journal Psychology of Education 32: 571-587.

[6] Sun, Q.Y. \& Hu, D.W. (2000).A Preliminary Study of the Transition from Kindergarten to Primary School. Anhui Education Newspaper, 02-08 [3].

[7] Wang, H.U. (2012). what kind of role that family education play in the transition from kindergarten to primary school. Education Tribune 2:83-85.

[8] Yang, X.P. \& Li, Z. J. (2004). The Study on the Cohesion of Chinese Curriculum from Kindergarten to Primary School, Pre-school education research.9: 42-44.

[9] Zhang, X.R. (1995). The Understanding of How to Do Well with the Work of Transition from Kindergarten to Primary School. Qinghai education, 3:23.

Nvjie Guo was born in Tangshan, China in Hebei province. She is currently a college student in Zhejiang Ocean University, Zhoushan, China. Her research interests include cross-culture communication and English teaching.

Jingiing Lu is an associate professor in Foreign Language College, Zhejiang Ocean University, Zhoushan, China. She received her M.A. degree in linguistics and applied linguistics from Huazhong University of Science and Technology, China in 2006. Her research interests include cross-culture communication, English teaching and discourse analysis.

Zhijie Chen was born in Qvzhou, China in Zhejiang province. She is currently a college student in Zhejiang Ocean University, Zhoushan, China. Her research interests include cross-culture communication and English teaching.

Han Xiao was born in Cangzhou, China in Hebei province. She is currently a college student in Zhejiang Ocean University, Zhoushan, China. Her research interests include cross-culture communication and English teaching. 